Note

\title{
STABLE CARBON AND NITROGEN ISOTOPIC FRACTIONATION BETWEEN DIET AND SWINE TISSUES
}

\author{
Gabriela Bielefeld Nardoto ${ }^{1}$; Patricia Barboza de Godoy ${ }^{2}$; Epaminondas Sansigolo de Barros \\ Ferraz $^{1}$; Jean Pierre Henry Balbaud Ometto ${ }^{1}$, Luiz Antonio Martinelli1* \\ ${ }^{1}$ USP/CENA - Lab. de Ecologia Isotópica, C.P. 96 - 13400-970 - Piracicaba, SP - Brasil \\ ${ }^{2}$ USP/CENA - Programa de Pós-Graduação em Energia Nuclear na Agricultura. \\ *Corresponding author <martinelli@cena.usp.br>
}

\begin{abstract}
Naturally occurring stable isotope ratios can be a powerful tool in studies of animal nutrition, provided that the assumptions required for dietary reconstruction are validated by studies such as the one presented here. The objective of this study was to document the magnitude of isotopic fractionation between swine diet and their different tissues. For this, the isotopic ratios of carbon and nitrogen of the diet and selected tissues (hair, nail, liver, muscle, fat and cartilage) were determined. The $\delta^{13} \mathrm{C}$ and $\delta^{15} \mathrm{~N}$ of the diet were $-15.9 \%$ and $1.3 \%$, respectively, and all $\delta^{15} \mathrm{~N}$ of swine tissues were 2.2 to $3.0 \%$ o enriched in ${ }^{15} \mathrm{~N}$ in relation to the diet. Little variation in $\delta^{15} \mathrm{~N}$ occurred among tissues, with exception to liver that was less enriched in ${ }^{15} \mathrm{~N}$ than the nail. Nail and hair presented no ${ }^{13} \mathrm{C}$ enrichment relative to diet. Cartilage was $\sim 1.0 \%$ o enriched in ${ }^{13} \mathrm{C}$ as compared to diet. Liver and muscle were on average $2.1 \%$ o more depleted in ${ }^{13} \mathrm{C}$ in relation to diet as well as fat tissues. Some of the $\mathrm{C}$ and $\mathrm{N}$ isotope ratios of swine tissues differed in organs, but the isotopic fractionation trends among tissues appears to be similar to other mammals. Therefore our data provide a good baseline to interpret stable isotope patterns in domestic mammals (such as swine) in controlled or semi-controlled experiments.
\end{abstract}

Key words: $\delta^{13} \mathrm{C}, \delta^{15} \mathrm{~N}$, dietary inputs, domestic pig, isotope ratios

\section{FRACIONAMENTO ISOTÓPICO DE CARBONO E NITROGÊNIO ENTRE A DIETA E TECIDOS DE PORCOS}

\begin{abstract}
RESUMO: O uso da abundância natural de isótopos estáveis pode ser uma ferramenta útil em estudos de nutrição animal, de forma que a base necessária para a reconstrução da dieta alimentar pode ser validada a partir de estudos como o apresentado aqui. O objetivo deste estudo foi documentar a magnitude do fracionamento isotópico entre a dieta e os tecidos de porcos domésticos. Para tanto, foram determinadas as razões isotópicas de carbono e nitrogênio de alguns tecidos selecionados (pêlo, unha, fígado, músculo, gordura e cartilagem). Os valores de $\delta^{13} \mathrm{Ce} \delta^{15} \mathrm{~N}$ da ração fornecida foram - $15,9 \%$ e $1,3 \%$, respectivamente. $\mathrm{O} \delta^{15} \mathrm{~N}$ desses tecidos ficou entre 2,2 e $3,0 \%$ mais enriquecido do que a dieta. Pouca variação no $\delta^{15} \mathrm{~N}$ ocorreu entre os tecidos analisados, exceto o fígado que foi significativamente menos enriquecido em ${ }^{15} \mathrm{~N}$ do que a unha. A unha e o pêlo não apresentaram enriquecimento em ${ }^{13} \mathrm{C}$ em relação à ração, enquanto a cartilagem ficou $\sim 1 \%$ mais enriquecida. Os tecidos de fígado e músculo foram, em média, 2,1\% mais leve em ${ }^{13} \mathrm{C}$ em relação à dieta, assim como o tecido adiposo. Várias das razões isotópicas dos tecidos dos porcos diferiram, mas as tendências no fracionamento isotópico entre os tecidos foram similares ao encontrado em outros mamíferos. Portanto as diferenças encontradas no fracionamento isotópico podem servir de base para a interpretação de padrões isotópicos em animais domésticos oriundos de experimentos controlados ou semi-controlados.
\end{abstract}

Palavras-chave: $\delta^{13} \mathrm{C}, \delta^{15} \mathrm{~N}$, consumo alimentar, razão isotópica, suíno

\section{INTRODUCTION}

Stable carbon and nitrogen isotope ratios of animal tissues represent a balance between dietary intake and loss. In general, when animals are close to a steady state nitrogen balance and their food source has a constant nitrogen $\left(\delta^{15} \mathrm{~N}\right)$ isotope ratio, their $\delta^{15} \mathrm{~N}$ val- ues in a specific tissue do not exhibit significant fluctuations. This assumption is the basis for using animal tissue isotopic compositions (more often nitrogen and carbon) to infer dietary inputs (Schwarcz \& Schoeninger, 1991). Furthermore, it is common to use stable isotope ratios of carbon $\left(\delta^{13} \mathrm{C}\right)$ and nitrogen in mass-balance equations in order to estimate dietary 
composition, carbon flow or dietary reconstruction (Ambrose \& Norr, 1993; Minagawa, 1992, Nardoto et al., 2006).

Variations in plant foliar $\delta^{13} \mathrm{C}$ values occur largely due to differences in the $\mathrm{C}_{3}$ and $\mathrm{C}_{4}$ photosynthetic pathways. As a result, $\mathrm{C}_{3}$ plants have $\delta^{13} \mathrm{C}$ values ranging from -35 to $-22 \%$ with an average of $27 \%$, while $\mathrm{C}_{4}$ plants range from -16 to $-9 \%$ and average of $-12.5 \%$ o (Farquhar et al., 1989). In contrast, plant $\delta^{15} \mathrm{~N}$ values can vary greatly due to a number of physiological (see review by Evans, 2001) and abiotic factors (Hobbie et al., 2000).

There is a systematic but poorly defined difference between the isotopic composition of the consumer tissues and that of the diet (an enrichment factor, expressed as $\Delta_{\text {tissue-diet }}$. Trophic levels and muscletissue enrichments can vary from 0.5 to $4.6 \%$ o for ${ }^{13} \mathrm{C}$ and 1.0 to $6.0 \%$ for ${ }^{15} \mathrm{~N}$ (Ambrose \& Norr, 1993; De Niro \& Epstein, 1978; 1981; Hare et al., 1991; Minagawa \& Wada, 1984; Schoeninger \& De Niro, 1984; Sponheimer et al., 2003a; 2003b). Once documented, diet-tissue fractionation can be used to interprete results of studies using stable isotope analysis. Therefore the objective of this study was to document the magnitude of the isotopic fractionation between diet and different swine tissues, and with this, to provide important baseline information to interprete diet patterns based on stable isotopic analysis of tissues.

\section{MATERIAL AND METHODS}

Five adult swine (Sus scrofa - breed "Seghers") were used in this study, that was carried out at Piracicaba, SP, Brazil $\left(22^{\circ} 44^{\prime}\right.$ S; $47^{\circ} 38^{\prime}$ W). We used female swine that were weaned until 21 days-old and thereafter fed the same diet (their sows were also fed with similar diet although they came from another experiment). They were slaughtered when they were 152 days-old and weighted $\sim 100 \mathrm{~kg}$. Samples from liver, muscle, cartilage and fat tissues were taken from each swine and immediately frozen. Lipids were not removed from the samples before being oven-dried and analyzed. Hair and nail were clipped from each swine, rinsed twice in distilled water for about $20 \mathrm{~min}$ each time. These samples were then dried overnight at $65^{\circ} \mathrm{C}$ and ground to a fine powder (to be homogenized) before analysis. All sampled tissues were placed in tin capsules $(0.5-1.0 \mathrm{mg}$ per sample) for isotopic analysis.

The feed-diet was composed of $25 \%$ soybean, $65 \%$ corn and $10 \%$ of a mixture containing phosphate, lime salt, vitamin, and a mineral mix (commercial product by Roche Inc.). Four samples of the diet were ground to a fine powder, homogenized, dried overnight at $65^{\circ} \mathrm{C}$ and then weighted $(1.0 \mathrm{mg})$ in these capsules.

Isotopic ratios of carbon $\left({ }^{13} \mathrm{C} /{ }^{12} \mathrm{C}\right)$ and nitrogen $\left({ }^{15} \mathrm{~N} /{ }^{14} \mathrm{~N}\right)$ of each sample were determined in a Thermo Quest-Finnigan Delta Plus isotope ratio mass spectrometer (Finnigan-MAT; CA, USA) interfaced to an Elemental Analyzer (Carla Erba model 1110; Milan, Italy). Stable isotope ratios are measured relative to internationally recognized standards, included in every run. Stable isotope contents are reported in "delta" $\delta$ values (\%o) where:

$$
\delta\left({ }^{\circ} /_{o o}\right)=\left(\frac{R_{\text {sample }}}{R_{\text {stan dard }}}-1\right) \cdot 1000
$$

which $\mathrm{R}$ is the molar ratio of the rare to the abundant isotope $\left({ }^{13} \mathrm{C} /{ }^{12} \mathrm{C}\right.$ or $\left.{ }^{15} \mathrm{~N} /{ }^{14} \mathrm{~N}\right)$ in the sample and in the standard. The $\delta$ notation describes, therefore, the relative amount of the heavier isotope in relation to the lighter. Therefore, a material with higher $\delta$ is described as isotopically enriched, a criterium adopted in this text hereafter. The carbon standard is Peedee Belemnite (PDB) and that for nitrogen, the atmospheric air. The precision of the isotope ratio measurements was $\pm 0.3 \%$ and $\pm 0.5 \%$ or $\delta^{13} \mathrm{C}$ and $\delta^{15} \mathrm{~N}$, respectively.

Data distribution was evaluated by the Kolmogorov-Smirnoff test for normality. Since the data were normally distributed, analyses were performed using parametric tests. ANOVA followed by a Post Hoc Fisher LSD test was used to determine differences among tissues. ANOVA followed by the Dunett test was used for comparisons with a control group (diet). All statistical analyses were performed using the software STATISTICA, version 6.1 for Windows (StatSoft, Inc. 2004). Differences at the 0.05 level were reported as significant.

\section{RESULTS AND DISCUSSION}

All swine tissue $\delta^{15} \mathrm{~N}$ values were ${ }^{15} \mathrm{~N}$ enriched in relation to the diet $(P<0.01)$ (Table 1). Little variation in $\delta^{15} \mathrm{~N}$ occurred among tissues (Figure 1). The only difference between tissues was that liver was significantly less enriched than nail $(P=0.0497)$. Results from controlled-feeding studies of herbivorous (Pinnegar \& Polunin, 1999; Sponheimer et al., 2003a) and carnivorous mammals (Roth \& Hobson, 2000) have also shown similar numbers of diet-tissue fractionation for nitrogen.

Nail and hair presented no significant ${ }^{13} \mathrm{C}$ enrichment relative to diet $(P=0.624$ and $P=0.749$, respectively) (Figure 2). Cartilage was $\sim 1.0 \%$ enriched in ${ }^{13} \mathrm{C}$ as compared to diet but this difference was not significant $(P=0.160)$. On the other hand, the more 
Table 1 - Difference between the isotopic composition of the tissues of the consumer (domestic pig) and of the feed-diet (an enrichment factor, expressed as $\Delta_{\text {tissue-diet }}$ ). The " $\Delta$ " was calculated according to Ambrose \& Norr (1993) and it means the difference between the $\delta^{13} \mathrm{C}$ or $\delta^{15} \mathrm{~N}$ of the tissue and the $\delta^{13} \mathrm{C}$ or $\delta^{15} \mathrm{~N}$ of the diet.

\begin{tabular}{lcc}
\hline Tissue & \multicolumn{2}{c}{$\begin{array}{c}\text { Fractionation between tissue and } \\
\text { feed-diet }\end{array}$} \\
\hline & $\Delta^{15} \mathrm{~N}$ & $\Delta^{13} \mathrm{C}$ \\
Nail & 3.0 & -0.3 \\
Hair & 2.7 & 0.2 \\
Cartilage & 2.5 & 0.9 \\
Muscle & 2.8 & -1.6 \\
Liver & 2.2 & -2.4 \\
Fat & 2.6 & -2.3 \\
\hline
\end{tabular}

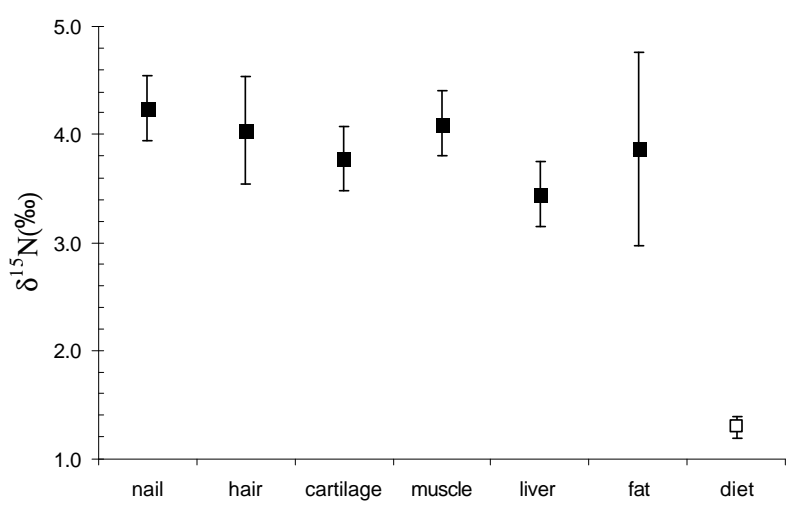

Figure 1 - Nitrogen isotope ratios for different tissues of domestic pigs and for their feed-diet (mean and standard deviation).

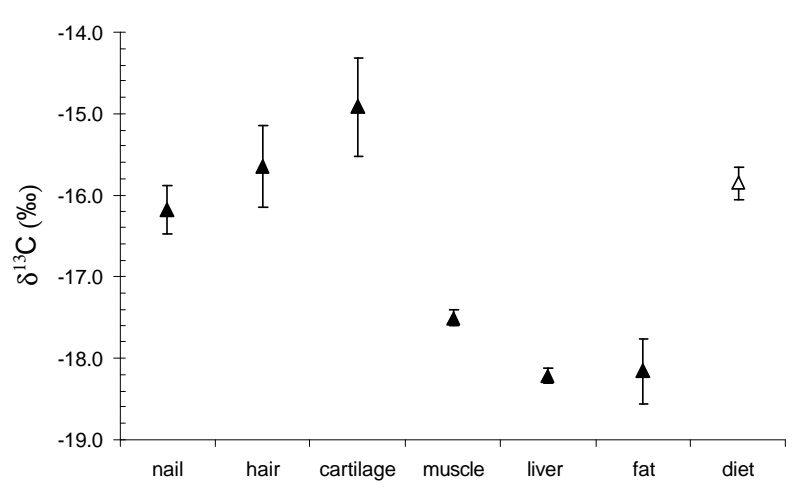

Figure 2 - Carbon isotope ratios for different tissues of domestic pigs and for their feed-diet (mean and standard deviation).

metabolic tissues like liver and muscle, as well as fat tissues were significantly depleted in ${ }^{13} \mathrm{C}(P=0.0082$, $P=0.0372$, and $P=0.0188$, respectively) (Table 1). The cause of these differences is not completely known (Pinnegar \& Polunin, 1999; Tieszen et al., 1983), they however might reflect variations in the biochemical composition of these tissues given that major biochemical compounds (proteins, carbohydrates, lipids, etc) differ isotopically from each other. For fat tissues depleted $\delta^{13} \mathrm{C}$ values have repeatedly been reported in the literature (Pinnegar \& Polunin, 1999; Roth \& Hobson, 2000; Tieszen et al., 1983) and, it is possible that a significant lipid content in the liver and muscle samples of this study contributed to the lower isotopic fractionation.

The $\delta^{15} \mathrm{~N}$ and $\delta^{13} \mathrm{C}$ values of the most important dietary components of the feed diet corn and soybean-were 2.99 and $-11.20 \%$ and -0.31 and $-25.39 \%$, respectively. The apparent diet-tissue isotopic variation for both carbon and nitrogen may be a consequence of differential contributions of dietary inputs into the isotope ratios of non essential amino acids (Schwarcz \& White, 2004). As an example, approximately two thirds of the $\mathrm{C}$ and $\mathrm{N}$ in the nail and hair keratin are derived from non essential amino acids. Since only one component of the diet, soybean, is the main source of protein, it seems reasonable to assume that this source was effective in determining the degree of protein routing in the animal, as demonstrated by Ambrose \& Norr (1993). Protein consumption rates should be a major factor in understanding the $\mathrm{N}$ contribution of the diet components because $\mathrm{N}$ from food is primarily found in proteins fractions, but for $\mathrm{C}$, protein is not the only potential source in animal tissues. Hence dietary protein may not be the only source that can alter the $\delta^{13} \mathrm{C}$ of animal tissues, although the contribution of $\mathrm{C}$ from carbohydrate and lipid to the protein component is still unknown. Minagawa (1992) demonstrated that estimations based on weighed ${ }^{13} \mathrm{C}$ and ${ }^{15} \mathrm{~N}$ for food calorie and protein content of the food isotope data were consistent with the isotope composition of human hair and that they were systematically related to bulk dietary inputs.

Despite these complications, the $\mathrm{C}$ and $\mathrm{N}$ isotope ratios of swine tissues, in general, differ in organs, but the isotopic trends among tissues appear to be similar in other mammals (De Niro \& Epstein, 1978; Roth \& Hobson, 2000; Tieszen et al., 1983; Tieszen \& Fagre, 1993). Measurements of these stable isotopes provide a powerful tool for understanding trophic relationships and tracing the flow of energy and nutrients. Stable isotope measurements can reflect assimilated food, not merely what has been recently ingested, and avoid biases inherent in analyzing scats or stomach containing items of different digestibility. However, tissue isotope ratios can vary within an individual raised on a constant diet, because isotopes fractionate differently between diet and various tissues (Tieszen et al., 1983). The mechanisms of isotopic fractionation 
(change in isotope ratios due to the different rates at which various isotopes undergo chemical reactions) between an animal diet and its tissues are still not well understood (Tieszen \& Boutton, 1989), but fractionation patterns must be known to interpret stable-isotope data (Gannes et al., 1997). These patterns have been documented in laboratory situations with animals raised on controlled diets (De Niro \& Epstein, 1978; 1981; Sponheimer et al., 2003a; 2003b; Tieszen et al., 1983; Tieszen \& Fagre, 1993) and have been measured in wild animals (Roth \& Hobson, 2000). However, no studies have measured diet-tissue isotopic fractionation in domestic pigs. Therefore our data provide a good baseline for interpreting stable isotope patterns in domestic mammals in a controlled or semi-controlled experiment.

Isotopic fractionation among tissues can be quite variable. However, the knowledge of isotopic fractionation of hair and nail are particularly valuable, since the stable isotope ratios of these tissues provide a nondestructive method of dietary reconstruction. Although there are lots of uncertainties related to the fate (routing x scrambling models, eg. Ambrose \& Norr, 1993) of the carbon and nitrogen in the body, the results from this controlled-feeding study in domestic pigs can, to some extent, suggest that isotopic fractionation factors can be applicable in future studies and the use of stable isotopes can be a helpful and complementary tool in nutrition studies on animals.

\section{ACKNOWLEDGEMENTS}

To CNPq (Project No. 141870/2003-6) and to L. Oetting, C.E. Utiyama, M.Z. Moreira, A. Araújo, D. Cappi, E. Tribuzi, M. Basso, M. Costa and N. Leite for their field and laboratory assistance.

\section{REFERENCES}

AMBROSE, S.H.; NORR, L. Experimental evidence for the relationship of the carbon isotope ratios of whole diet and dietary protein to those of bone collagen and carbonate. In: LAMBERT, J.B.; GRUPE, G. (Ed.). Prehistoric human bone: Archaeology at the molecular level. Berlin: Springer-Verlag, 1993. p.1-37.

De NIRO, M.J.; EPSTEIN, S. Influence of diet on the distribution of carbon isotopes in animals. Geochimica et Cosmochimica Acta, v.42, p.495-506, 1978.

De NIRO, M.J.; EPSTEIN, S. Influence of diet on the distribution of nitrogen isotopes in animals. Geochimica et Cosmochimica Acta, v.45, p.341-351, 1981.

EVANS, R.D. Physiological mechanisms influencing plant nitrogen isotope composition. Trends in Plant Science, v.6, p.121-126, 2001.

FARQUHAR, G.D.; EHLERINGER, J.R.; HUBICK, K.T. Carbon isotope discrimination and photosynthesis. Annual Review in Plant Physiology and Plant Molecular Biology, v.40, p.503-537, 1989.
GANNES, L.Z.; O’BRIEN, D.M.; MARTINEZ del RIO, C. Stable isotopes in animal ecology: assumptions, caveats, and a call for more laboratory experiments. Ecology, v.78, p.1271-1276, 1997.

HARE, P.E.; FOGEL, M.L.; STAFFORD Jr., T.W.; MITCHELL, A.D.; HOERING, T.C. The isotopic composition of carbon and nitrogen in individual amino acids isolated from modern and fossil proteins. Journal of Archaeological Science, v.18, p.277-292, 1991.

HOBBIE, E.A.; MACKO, S.A.; WILLIAMS, M. Correlations between foliar delta N-15 and nitrogen concentrations may indicate plantmycorrhizal interactions. Oecologia, v.122, p.273-283, 2000.

MINAGAWA, M. Reconstruction of human diet from $\delta^{13} \mathrm{C}$ and $\delta^{15} \mathrm{~N}$ in contemporary Japanese hair: A stochastic method for estimating multi-source contribution by double isotopic tracers. Applied Geochemistry, v.7, p.145-158, 1992.

MINAGAWA, M.; WADA, E. Stepwise enrichment of N-15 along foodchains - Further evidence and the relation between Delta-N-15 and animal age. Geochimica et Cosmochimica Acta, v.48, p.1135-1140, 1984.

NARDOTO, G.B.; SILVA, S.; KENDALL, C.; EHLERINGER, J.R.; CHESSON, L.A.; FERRAZ, E.S.B.; MOREIRA, M.Z.; OMETTO, J.P.H.B.; MARTINELLI, L.A. Geographical patterns of human diet derived from stable-isotope analysis of fingernails. American Journal of Physical Anthropology, v.131, p.137-146, 2006.

PINNEGAR, J.K.; POLUNIN, N.V.C. Differential fractionation of delta C-13 and delta N-15 among fish tissues: implications for the study of trophic interactions. Functional Ecology, v.13, p.225-231, 1999.

ROTH, J.D.; HOBSON, K.A. Stable carbon and nitrogen isotopic fractionation between diet and tissue of captive red fox: implications for dietary reconstruction. Canadian Journal of Zoology, v.78, p.848-852, 2000.

SCHOENINGER, M.J.; De NIRO, M.J. Nitrogen and carbon isotopic composition of bone collagen from marine and terrestrial animals. Geochimica et Cosmochimica Acta, v.48, p.625-639, 1984.

SCHWARCZ, H.P.; SCHOENINGER, M.J. Stable isotope analyses in human nutritional ecology. Yearbook of Physical Anthropology, v.34, p.283-321, 1991.

SCHWARCZ, H.P.; WHITE, C.D. The grasshopper or the ant?: Cultigenuse strategies in ancient Nubia from C-13 analyses of human hair. Journal of Archaeological Science, v.31, p.753-762, 2004.

SPONHEIMER, M.; ROBINSON, T.; AYLIFFE, L.; ROEDER, B.; HAMMER, J.; PASSEY, B.; WEST, A.; CERLING, T.; DEARING, D.; EHLERINGER, J. Nitrogen isotopes in mammalian herbivores: hair $\delta^{15} \mathrm{~N}$ values from a controlled feeding study. International Journal of Osteoarchaeology, v.13, p.80-87, 2003a.

SPONHEIMER, M.; ROBINSON, T.; AYLIFFE, L.; PASSEY, B.; ROEDER, B.; SHIPLEY, L.; LOPEZ, E.; CERLING, T.; DEARING, D.; EHLERINGER, J. An experimental study of carbon-isotope fractionation between diet, hair, and feces of mammalian herbivores. Canadian Journal of Zoology, v.81, p.871-876, 2003b.

STATSOFT INC. Statistica. Data analysis software system. Version 6.1. 2004. Available in: http://www.statsoft.com.

TIESZEN, L.L.; FAGRE, T. Effect of diet quality and composition on the isotopic composition of respiratory $\mathrm{CO}_{2}$, bone collagen, bioapatite, and soft tissues. In: LAMBERT, J.B.; GRUPE, G. (Ed.). Prehistoric human bone - Archaeology at the molecular level. Berlin: SpringerVerlag, 1993. p.121-155.

TIESZEN, L.L.; BOUTTON, T.W. Stable carbon isotopes in terrestrial ecosystem research. In: RUNDEL, P.W.; EHLERINGER J.R.; NAGY, K.A. (Ed.). Stable isotopes in ecological research. Berlin: SpringerVerlag, 1989. p.167-195.

TIESZEN, L.L.; BOUTTON, T.W.; TESDAHL, K.G.; SLADE, N.A. Fractionation and turnover of stable carbon isotopes in animalTissues - Implications for Delta-C-13 analysis of diet. Oecologia, v.57, p.32-37, 1983.

Received February 16, 2006

Accepted October 16, 2006 